\title{
Financial forecasting for self-sufficiency and food security in poultry meat
}

\author{
Mohamad Alnafissa $^{1}$ (D) . Adel Ghanem ${ }^{1} \cdot$ Yosef Alamri $^{1}$. Jawad Alhashim ${ }^{1}$. \\ Fuad Alagsam ${ }^{1}$
}

Received: 4 May 2020 / Accepted: 23 March 2021 / Published online: 5 April 2021

(C) The Author(s), under exclusive licence to Springer Nature B.V. 2021

\begin{abstract}
This study estimates the need for financing and water to achieve self-sufficiency and food security in the poultry meat industry in Saudi Arabia. This study was based on secondary data and economic and statistical equations. The indexes related to the food security applied and the need for financing and water for poultry meat were calculated. According to the study, poultry meat's strategic stock is estimated at 658.1 thousand tons, which is enough for local consumption for 152.7 days. Meanwhile, the food security factor for poultry meat is estimated at 0.42 for the end of the period 1995-2018. The required investments to achieve full self-sufficiency and food security for poultry meat are estimated at 218.19 million Riyals and 671.21 million Riyals, respectively. Achieving self-sufficiency and food security in poultry meat also requires 6.29 billion $\mathrm{m}^{3}$ water worth 3.03 billion Riyals. This study recommends that industry leaders increase their investment in the private sector to achieve self-sufficiency and food security for poultry meat. This suggestion is consistent with the national transformation program and the Kingdom's 2030 vision, in addition to population growth, through the Agricultural Development Fund, which should increase the loans and investments needed to create new projects or expand the existing projects' production capacity.
\end{abstract}

Keywords Financing needs $\cdot$ Water $\cdot$ Self-sufficiency $\cdot$ Food security $\cdot$ Poultry meat

Mohamad Alnafissa

malnafissa@ksu.edu.sa

Adel Ghanem

aghanem@ksu.edu.sa

Yosef Alamri

yosef@ksu.edu.sa

Jawad Alhashim

jalhashim@ksu.edu.sa

Fuad Alagsam

falagsam@ksu.edu.sa

1 Department of Agricultural Economics, College of Food and Agricultural Sciences, King Saud University, P. O. Box 2460, Riyadh 11451, Saudi Arabia 


\section{Introduction}

Food, water scarcity, and weather inclemency are strategic issues of concern to Saudi Arabia (Alqahtani et al., 2017). The government strives to provide food to alleviate food insecurity in conjunction with rationalizing water consumption and increasing productivity (Saudi Arabia's 2030 Vision, 2016). The Agricultural Development Fund has launched seven initiatives to rationalize the use of water, thereby improving agricultural production efficiency. Increasing poultry production is one of these initiatives.

The government is driven by three contributing factors to prioritize poultry production concerning food security. First, poultry production requires less water than red meat (Daghir et al., 2018). Second, the poultry industry's investment provides animal protein in a timely manner and improves food security in the short run due to its characteristics of relatively higher food transformative efficiency and quicker fattening than other animal sources. Third, poultry production incurs relatively lower cost, presents the advantage of speedy capital turnover, and requires limited space (Agricultural Development Fund, 2019).

The increase in Saudi Arabia's population led to increased poultry meat demand by an average of 1361.5 thousand tons during 2016-2018. Self-sufficiency in poultry meat decreased from $68.9 \%$ in 1995 to $48.6 \%$ in $2017 .{ }^{1}$ Under the national transformation program for the agricultural sector, the government aims to raise poultry meat's self-sufficiency rate from $42 \%$ in 2016 to $60 \%$ by 2020 to reduce the gap between domestic production and consumption. The availability of a strategic stockpile will achieve food security and ensure price stability and the continuous flow of poultry meat to local markets, which will warrant price stability and the prevention of food crises, especially considering the emergency economic conditions.

The production of poultry meat in the quantity that achieves the government goal of $60 \%$ self-sufficiency in poultry production would require a large amount of water, while water is currently scarce in Saudi Arabia. Moreover, the availability of financing would support the increased self-sufficiency in poultry meat in Saudi Arabia.

Therefore, this paper's primary objective is to estimate the amounts of both water and financial requirements to bridge the gaps between consumption and production and achieve self-sufficiency and food security. The secondary objective is to investigate the current statuses of poultry self-sufficiency and food security. Unlike previous studies focusing on Saudi Arabia that only considered current and expected trends of poultry food security (e.g., Alamri \& Al-Duwais, 2019), this study will fill the gap in the existing literature by estimating water and financial needs to reach the government target of self-sufficiency and food security in poultry production. The results will help policymakers align their efforts to overcome food insecurity and rationalize the use of scarce water use.

The remainder of this paper consists of four sections. The first section represents the literature review. The second and third sections introduce this paper's objectives and the implemented research methodology. The fourth section represents the results, and the fifth concludes.

\footnotetext{
${ }^{1}$ Food security of poultry meat is also affected by the amount of food loss and waste. The total amount of food loss and waste for poultry meat reached 444 thousand tons worth 2799 million Riyals, representing $21.56 \%$ of the total value of food loss and waste in Saudi Arabia in 2018, which was 12.98 billion Riyals (General Organization for Grains, 2019).
} 


\section{Literature review}

Several economic studies have addressed the issue of self-sufficiency and food security. Self-sufficiency is a part of food security subject to production ability. Studies such as Antamoshkina and Rogachev (2019) presented a model to assess agricultural policy effectiveness through comprehensive indicators obtained by the aggregation of economics and financial and social indicators. The indicator's result helps guide the policymaker regarding whether the agricultural policy is moving in the correct direction or not to develop food security. However, the indicator value does not provide how much investment or resources to reach food security.

On the other hand, some studies find that the poultry farming sector is the primary vector to reach self-sufficiency and food security if the produce provides technical performance (Cecilia et al., 2017). Cecilia and other authors used mixed indicators and SWAT analysis to reach these conclusions. The SWAT analysis reveals that one of the strengths for Romania has the agricultural resources to feed the livestock animals, while one of the threads is the uncertainties on agricultural funding from the EU source. However, the study estimates the public funding needed to invest in the poultry sector to reach self-sufficiency while ignoring the necessary agricultural resources to reach the target. Also, Chen and Nie (2016) reference three points discussing food security in China: First, the self-sufficiency rate must be realistic and reviewed whenever needed according to the balance between supply and demand in the international market. The second relates to the need to raise the efficiency of the resources used in agriculture, such as water and land resources, and the third regards the need to define the mechanisms that change the prices of the future food market through the market mechanism. The three points mentioned above became necessary when the coronavirus (COVID-19) pandemic emerged and some countries closed their borders while others reduced their foodstuffs export. However, Chen and Nie (2016) ignored the importance of agricultural financing to reach food security, which may be because agricultural financing in China is not a problem.

Several studies covered the food security issue in Saudi Arabia. In 2012, the Riyadh Economic Forum studied food security among domestic agriculture, import, and external agricultural investment and found a relative difference between production and actual consumption and their target counterpart for poultry meat. Given the strategic stockpile and the expected average domestic consumption of poultry meat, the food security factor is estimated at 0.52 during 2011-2020. This result is confirmed by Alamri and Al-Duwais (2019), who found that Saudi Arabia has good self-sufficiency in poultry from local production compared to wheat and barley. The same study found that poultry's average strategic stock was enough to cover the domestic consumption period for only 4.33 days. For the estimation in the future period of 2017-2021, the study by Alderiny et al. (2020) anticipated a small decrease in the annual chicken meat import by a rate between 0.52 and $0.20 \%$, depending on the exporting countries, in addition to the increase in the annual import prices of the same product and the increase in the expected self-sufficiency ratio to $57.4 \%$ in 2021. This means that the Saudi government cannot achieve its objective in 2020 if the present conditions do not change.

On the other hand, Daghir et al. (2018) examined the water footprint of animal products in the Middle East/North Africa region and found that it ranged from a minimum of $862 \mathrm{~m}^{3} /$ ton for milk and a maximum of 15.62 thousand $\mathrm{m}^{3} /$ ton for beef, and the same measure for poultry meat and egg production was much lower than the estimated need for red meat. This study showed that $90 \%$ of the water required for animal products goes toward feed production. Thus, 
increased self-sufficiency and food security lead to an increase in the demand for water used directly or indirectly to produce poultry meat. However, previous studies examined food selfsufficiency and food security by developing a methodology to measure indicators and predict the future of the self-sufficiency rate. Thus, we raise the following question: how can decisionmakers reach the desired goal of self-sufficiency and food security, and how many resources are needed to reach it? Therefore, the study investigates how much funding Saudi Arabia needs to help the private sector to invest in the poultry meat sector. Furthermore, water is a scarce resource in Saudi Arabia; therefore, the decision-maker must know how much water is needed to increase the broiler chicken's self-sufficiency ratio.

\section{Research objectives}

Drawn from the government's concern about food security and the goal of increasing poultry self-sufficiency, the objectives of this paper are as follows:

- To investigate the current and future trends for statuses of poultry self-sufficiency and food security.

- To estimate the water and financial resources required to achieve the government's goal for self-sufficiency and food security.

\section{Research methodology}

The methodology follows several steps to achieve the objective of the study. Therefore, the following economic and statistical equations estimate the financial and water required to achieve self-sufficiency and food security in poultry meat:

(A) Indicators to measure self-sufficiency and food security ratios for poultry meat.

Equation (1) measures the self-sufficiency ratio, where DP represents the domestic production and DC represents the domestic consumption.

$$
\begin{gathered}
\text { Self }- \text { Sufficiency ratio }=\left(\frac{\mathrm{DP}}{\mathrm{DC}}\right) \times 100 \\
\mathrm{~A}=\frac{\mathrm{DP}}{\mathrm{DDC}} \\
\mathrm{B}=\frac{Q^{I}}{\mathrm{DDC}} \\
\mathrm{C}=[(\mathrm{D}-365) \times(\mathrm{DDC})]-\mathrm{Q}^{E} \quad(\text { Ghanem, 1997) } \\
\mathrm{FSC}_{\text {meat }}=\left(\frac{E}{\mathrm{DC}}\right)
\end{gathered}
$$


Equation (2) measures A, which is the period of sufficient production for domestic consumption. DDC represents daily domestic consumption. Equation (3) measures $B$, which is the period of import coverage for domestic consumption. $Q^{I}$ represents the quantity of imports. Equation (4) measures $C$, which is the amount of surplus and deficit in meat. $D$ is the total length of the period of the adequacy of production and coverage of imports, and $Q^{E}$ : is the quantity of export. Equation (5) measures $\mathrm{FSC}_{\text {meat }}$, which is the food security coefficient of meat, and $E$ is the volume of the strategic stockpile.

The value of the food security coefficient ranges from zero to one, where the volume of the strategic stockpile $(E)$ is located between zero and infinity, and domestic consumption (DC) must be greater or equal to the volume of the strategic stockpile $(E)$ and is not zero. The food security coefficient value will be zero in the food insecurity case. In contrast, the food security coefficient value will equal to one in the case of complete food security (Ghanem \& Kamara, 2010).

(B) Binomial distribution was used to estimate the percentage or probability of contribution to achieve self-sufficiency and food security at a 95\% confidence level using standard errors and confidence intervals as follows:

$$
\text { Probability error of } 95 \%=\sqrt{\frac{P(1-P)}{N}} \times 1.96 \pm
$$

The $95 \%$ confidence interval for the probability $=\sqrt{\frac{P(1-P)}{N}} \times(P \pm 1.96)$

where, $(P)$ is the probability of contributing to self-sufficiency and food security, $(1-P)$ is the probability of not contributing, and $N$ is the length of the time series (Greene, 2003).

(C) The equations used to estimate the needs of financing to achieve self-sufficiency and food security for poultry meat are as follows (Ghanem et al., 2019):

$$
\begin{gathered}
\mathrm{F}=\mathrm{I} \times \mathrm{E} \\
\mathrm{K}=\mathrm{L} \times \mathrm{F} \\
\mathrm{N}=\mathrm{K}+\mathrm{V}^{\mathrm{I}}
\end{gathered}
$$

where, $\mathrm{F}$ is the increase in domestic production needed to achieve food security, $\mathrm{I}$ is the relative importance of the contribution of domestic production, $\mathrm{K}$ is the value of the additional investments needed to achieve self-sufficiency and food security, L is the average unit per ton (tons) of meat from investments, $\mathrm{F}$ is the increase in domestic production needed to achieve self-sufficiency and food security, $\mathrm{N}$ is the total value of financing needed to achieve food security, and $\mathrm{V}^{\mathrm{I}}$ is the value of imports.

(D) The equations used to estimate the quantity and value of the water needed to achieve self-sufficiency and food security for poultry meat are as follows:

$$
\text { Water_SC } \mathrm{PM}_{\mathrm{PM}}=\mathrm{DP} \times \mathrm{FP}_{\mathrm{PM}}
$$




$$
\begin{gathered}
\text { Water_FS } \\
\text { PM }=C \times \text { FP }_{\mathrm{PM}} \\
\text { Value_Water }_{\mathrm{PM}}=\text { Water_SC } \mathrm{PM}_{\mathrm{PM}} \times \text { Cost }_{\text {water }}
\end{gathered}
$$

where Water_SC $\mathrm{PM}_{\mathrm{PM}}$ is the amount of water used to achieve self-sufficiency of poultry meat, $\mathrm{FP}_{\mathrm{PM}}$ is the average water requirements or water footprint to produce a ton of poultry meat, Water_FS $\mathrm{PM}_{\mathrm{PM}}$ is the amount of water used to achieve food security for poultry meat, Value Water $_{\mathrm{PM}}$ is the water needed to achieve self-sufficiency and food security, and Cost ${ }_{\text {water }}$ is the average cost per unit of groundwater extraction.

\section{Data requirement}

The study aims to estimate the financial and water resource needs to achieve food security within the poultry meat industry. The data related to study variables from 1995 to 2018 were collected from different sources. This study was based on secondary data published in each of the surveys from specialized agricultural projects, export-import statistics issued by the General Authority for Statistics (GASTAT); the annual reports issued by the Agricultural Development Fund, the statistical book issued by the Ministry of Environment, Water, and Agriculture, the Food and Agriculture Organization (FAOSTAT); and previous studies. However, the first section of the methodology aims to measure the self-sufficiency and food security indicators. Therefore, Table 1 provides the time series for the following variables: domestic production (DP), quantity imported $\left(Q^{\mathrm{I}}\right)$, quantity export $\left(\mathrm{Q}^{\mathrm{E}}\right)$, and daily domestic consumption (DDC). The daily domestic consumption represents the net domestic consumption divide by 365 , which are the year's days. The net domestic consumption equals the sum of domestic production plus quantity imported minus quantity exported. Also, the study calculated the volume of strategic stockpiles (E). E is a sum of the cumulative deficit and surplice in meat. More precisely, the $\mathrm{E}$ is equal (C) during the period (t) in which $\mathrm{E}_{\mathrm{T}}$ represents the cumulative stock at the end of period T to equal Ct's sum. Table 1 shows that the strategic stock at the end of 2018 was 658.1 thousand tons, while the food security coefficient is 0.42 . Table 1 also shows the summary statistic for the variables for which the average domestic production is around 533 thousand tons, while daily domestic consumption is 4.41 tons. On the other hand, during that period, Saudi Arabia exported poultry meat; the average export quantity was 5.4 thousand tons.

The study estimated the additional loans and investments required to achieve self-sufficiency for poultry meat. The main variables to estimate are the value of the additional investments needed $(\mathrm{K})$ and the value of imports $\left(\mathrm{V}^{\mathrm{I}}\right)$. Estimation of the additional investment needed (K) required data about the average unit per ton (tons) of meat from investments (L) and the increase in domestic production needed to achieve self-sufficiency and food security (F). The study used a different scenario to estimate the $F$ variable through the applied Eq. (1). The variable L is estimated through several steps. The first step was to estimate the average share of a ton of poultry meat from loans from 2014 to 2018, as shown in Table 2, which is 267 SR per ton. The second step was to multiply it by the difference between the domestic consumption in 2018 and the expected production level at a certain level of self-sufficiency. The third step is to estimate (L) by multiplying the difference between the domestic consumption in 2018 and the expected production level at a certain level of self-sufficiency by the average share of a ton of poultry meat from loans the period of 2014-2018. Considering the lending regulations of the Agricultural Development Fund, 
Table 1 Time series of variables during 1995-2018 and summary data description Sources Collected from (1) Food and Agriculture Organization (FAOSTAT), 1995-2018; (2) Ministry of Environment, Water, and Agriculture Statistical Book, 2019; and (3) General Authority for Statistics, Export, and Import Statistics, 1995-2018

\begin{tabular}{|c|c|c|c|c|}
\hline Year & $\begin{array}{l}\text { Domestic production } \\
\text { (thousand tons) }\end{array}$ & $\begin{array}{l}\text { Daily domestic consump- } \\
\text { tion (thousand tons) }\end{array}$ & $\begin{array}{l}\text { Import quantity } \\
\text { (thousand tons) }\end{array}$ & $\begin{array}{l}\text { Export quantity } \\
\text { (thousand tons) }\end{array}$ \\
\hline 1995 & 390 & 1.55 & 264.9 & 8.9 \\
\hline 1996 & 397 & 1.50 & 231.6 & 11.6 \\
\hline 1997 & 451 & 1.76 & 213.0 & 19.1 \\
\hline 1998 & 395 & 1.76 & 277.0 & 23.9 \\
\hline 1999 & 418 & 2.13 & 366.3 & 5.4 \\
\hline 2000 & 483 & 2.17 & 327.5 & 19.6 \\
\hline 2001 & 475 & 1.90 & 322.9 & 17.3 \\
\hline 2002 & 467 & 2.04 & 334.4 & 8.9 \\
\hline 2003 & 468 & 2.16 & 413.4 & 26.8 \\
\hline 2004 & 522 & 2.39 & 378.4 & 24.3 \\
\hline 2005 & 537 & 2.66 & 468.4 & 29.7 \\
\hline 2006 & 535 & 2.53 & 432.8 & 34.5 \\
\hline 2007 & 508 & 2.54 & 480.2 & 36.9 \\
\hline 2008 & 459.5 & 2.48 & 493.7 & 16.9 \\
\hline 2009 & 494 & 2.83 & 584.6 & 34.6 \\
\hline 2010 & 447 & 2.97 & 688.2 & 24.8 \\
\hline 2011 & 529 & 3.44 & 788.4 & 27.1 \\
\hline 2012 & 588 & 3.61 & 803.9 & 21.6 \\
\hline 2013 & 569 & 3.66 & 879.4 & 34.1 \\
\hline 2014 & 639.2 & 3.91 & 820.0 & 30.6 \\
\hline 2015 & 612.3 & 4.19 & 930.2 & 27.3 \\
\hline 2016 & 625.7 & 4.10 & 899.0 & 33.4 \\
\hline 2017 & 615.9 & 3.47 & 707.1 & 20.0 \\
\hline 2018 & 1164.6 & 4.31 & 449.8 & 38.0 \\
\hline Mean & 532.9 & 2.75 & 523.1 & 23.97 \\
\hline \multicolumn{4}{|c|}{ Strategic stock (E) } & 658.10 \\
\hline \multicolumn{4}{|c|}{ Food security coefficient } & 0.42 \\
\hline Maximum & 1164.6 & 4.31 & 930.2 & 38 \\
\hline Minimum & 390 & 1.50 & 213 & 5.4 \\
\hline
\end{tabular}

including the subsidized $50 \%$ of the total investment costs of the projects to be established, the additional investment required to achieve self-sufficiency for poultry meat is twice the value of the loans.

Furthermore, the study estimates the quantity and value of the water needed to achieve self-sufficiency and food security, and the primary variable to estimate the quantity of water needed is the average water requirements or water footprint to produce a ton of poultry meat (FPPM) and the average cost per cubic meter of groundwater extraction. The study used the previous study to estimate the average water requirement shown in Table 3 and estimated the average by 3995.9 cubic meters of water. The study also adopted the average cost of a cubic meter of groundwater, estimated by 0.482 Riyals $/ \mathrm{m} 3$ at a discount of $10 \%$ (Nashwan et al., 2016). 
Table 2 The average share of a ton of poultry meat from loans during the period of 2014-2018 Source Compiled and computed from (1) Agricultural Development Fund, Annual Report, 2014-2018 and (2) General Authority for Statistics, Survey of Specialized Agricultural Projects Survey (Broiler, Ostrich, Rabbit, Quail, and Pigeon Farms), 2019

\begin{tabular}{llll}
\hline Year & $\begin{array}{l}\text { Poultry production (thou- } \\
\text { sand tons) }\end{array}$ & $\begin{array}{l}\text { Amount of loans for poultry projects } \\
\text { (million Riyals) }\end{array}$ & $\begin{array}{l}\text { Share of tons of } \\
\text { loans (Riyals/ton) }\end{array}$ \\
\hline 2014 & 639.2 & 199.0 & 311.3 \\
2015 & 612.3 & 315.0 & 514.5 \\
2016 & 625.7 & 91.0 & 145.4 \\
2017 & 615.9 & 150.0 & 243.5 \\
2018 & 1164.6 & 140.0 & 120.2 \\
Average & 731.5 & 179.0 & 267.0 \\
\hline
\end{tabular}

Table 3 Average water requirement (water footprint) for poultry meat (cubic meter/ton)

\begin{tabular}{ll}
\hline Source & $\begin{array}{l}\text { Water requirements } \\
\text { cubic meter per ton }\end{array}$ \\
\hline Chapagain and Hoekstra (2003) & 2828 \\
Zimmer and Renault (2003) & 4100 \\
Oki et al. (2003) & 4500 \\
Water footprint network website and UNESCO & 5839 \\
$\quad$ reports & 2710 \\
Daghir et al. (2018) & 3995.4 \\
Average & \\
\hline
\end{tabular}

\section{Results}

\subsection{The current status of self-sufficiency and food security for poultry meat}

The current state of self-sufficiency and food security for poultry meat during 1995-2018 showed that domestic poultry meat production increased annually at $2.5 \%$, whereas daily local consumption increased at an annual growth rate of $4.4 \%$, according to the result provided in Table (5). Given the higher growth rate in domestic consumption than in production, poultry meat's self-sufficiency ratio declined from $68.9 \%$ in 1995 to $48.6 \%$ in 2017, then increased to $73.8 \%$ in 2018 (Table 4). However, the present study obtained similar results as those expected for the Agricultural Development Fund strategy and the National Transformation Program (2019) by raising the self-sufficiency rate to $60 \%$ in 2020 .

Therefore, the poultry meat imports increased from 264.9 thousand tons in 1995 to 707.1 thousand tons in 2017 and then decreased to 449.8 thousand tons in 2018, owing to the insufficient production for domestic consumption (Table 1). Poultry meat imports increased at an annual growth rate of $5.7 \%$ (Table 5).

The period of sufficient production for domestic consumption decreased at a rate of $1.9 \%$ annually, whereas import coverage for domestic consumption increased at an annual growth rate of $1.3 \%$. Surplus and deficit estimation showed that the strategic stock of poultry meat is 658.1 thousand tons. 
Table 4 Evolution of indicators of self-sufficiency and food security of poultry meat during 1995-2018 Sources Collected and calculated from (1) Food and Agriculture Organization (FAOSTAT), 1995-2018; (2) Ministry of Environment, Water, and Agriculture Statistical Book, 2019; and (3) General Authority for Statistics, Export and Import Statistics, 1995-2018

\begin{tabular}{|c|c|c|c|c|}
\hline Year & $\begin{array}{l}\text { Self-sufficiency } \\
(\%)\end{array}$ & $\begin{array}{l}\text { Period of sufficient pro- } \\
\text { duction (day) }\end{array}$ & $\begin{array}{l}\text { Period of import cover- } \\
\text { age (day) }\end{array}$ & $\begin{array}{l}\text { Surplus and deficit } \\
\text { (thousand tons) }\end{array}$ \\
\hline 1995 & 68.9 & 251.6 & 170.9 & 80.25 \\
\hline 1996 & 72.5 & 264.7 & 154.4 & 69.50 \\
\hline 1997 & 70.2 & 256.3 & 121.0 & 2.50 \\
\hline 1998 & 61.5 & 224.4 & 157.4 & 5.70 \\
\hline 1999 & 53.8 & 196.2 & 172.0 & 1.45 \\
\hline 2000 & 61.0 & 222.6 & 150.9 & -1.15 \\
\hline 2001 & 68.5 & 250.0 & 169.9 & 87.10 \\
\hline 2002 & 62.7 & 228.9 & 163.9 & 47.90 \\
\hline 2003 & 59.4 & 216.7 & 191.4 & 66.20 \\
\hline 2004 & 59.8 & 218.4 & 158.3 & 3.75 \\
\hline 2005 & 55.3 & 201.9 & 176.1 & 4.80 \\
\hline 2006 & 57.9 & 211.5 & 171.1 & 9.85 \\
\hline 2007 & 54.8 & 200.0 & 189.1 & 24.20 \\
\hline 2008 & 50.8 & 185.3 & 199.1 & 31.10 \\
\hline 2009 & 47.8 & 174.6 & 206.6 & 11.05 \\
\hline 2010 & 41.2 & 150.5 & 231.7 & 26.35 \\
\hline 2011 & 42.1 & 153.8 & 229.2 & 34.70 \\
\hline 2012 & 44.6 & 162.9 & 222.7 & 52.65 \\
\hline 2013 & 42.6 & 155.5 & 240.3 & 78.40 \\
\hline 2014 & 44.8 & 163.5 & 209.7 & 1.45 \\
\hline 2015 & 40.0 & 146.1 & 222.0 & -14.15 \\
\hline 2016 & 41.8 & 152.6 & 219.3 & -5.20 \\
\hline 2017 & 48.6 & 177.5 & 203.8 & 36.45 \\
\hline 2018 & 73.8 & 270.2 & 104.4 & 3.25 \\
\hline \multicolumn{4}{|c|}{ Strategic stock $(\mathrm{E})$} & 658.10 \\
\hline \multicolumn{4}{|c|}{ Food security coefficient } & 0.42 \\
\hline
\end{tabular}

Local consumption is sufficient for 152.7 days or 5.09 months. In 2018, the strategic stock and domestic consumption of poultry meat were 1573.15 thousand tons; thus, at the end of 1995-2018, the food security coefficient of poultry meat was 0.42 , which was lower than that reported by the Riyadh Economic Forum (2012), that is, 0.52 in 2011-2020.

The average domestic production covered only $53 \%$ of the average domestic consumption during the study period, which led to an increase in poultry meat prices and the subsequent increase in poultry meat imports. Thus, the government bore the increased burden of the budget and decreased food security by failing to take precautions against the poultry-exporting countries' economic and political fluctuations. 
Table 5 General trend equations for the evolution of self-sufficiency indicators and poultry meat food security during 1995-2018 Source Collected and calculated from the data presented in Table 1

\begin{tabular}{|c|c|c|c|c|}
\hline & $\begin{array}{l}\text { Annual growth } \\
(\%)\end{array}$ & $F$ & $R^{2}$ & Equation \\
\hline Domestic production & 2.5 & 38.63 & 0.64 & $\begin{array}{c}\operatorname{Ln} Y_{1}=5.929+0.025 X \\
(100.70)^{* *}(6.22)^{* *}\end{array}$ \\
\hline Daily consumption & 4.4 & 376.16 & 0.94 & $\begin{array}{c}\operatorname{Ln} Y_{2}=0.406+0.044 X \\
(12.36)^{* *}(19.39)^{* *}\end{array}$ \\
\hline Self-sufficiency & -1.9 & 18.96 & 0.46 & $\begin{array}{c}\operatorname{Ln} Y_{3}=4.229-0.019 X \\
(67.86)^{* *}(-4.35)^{* *}\end{array}$ \\
\hline Import quantity & 5.7 & 87.18 & 0.80 & $\begin{array}{c}\operatorname{Ln} Y_{4}=5.444+0.057 X \\
(61.86)^{* *}(9.34)^{* *}\end{array}$ \\
\hline Export quantity & 4.5 & 14.17 & 0.39 & $\begin{array}{c}\operatorname{Ln} Y_{5}=2.517+0.045 X \\
(14.81)^{* *}(3.76)^{* *}\end{array}$ \\
\hline Period of sufficient production & -1.9 & 18.75 & 0.46 & $\begin{array}{c}\operatorname{Ln} Y_{6}=5.524-0.019 X \\
(88.37)^{* *}(-4.33)^{* * *}\end{array}$ \\
\hline Period of import coverage & 1.3 & 5.46 & 0.20 & $\begin{array}{c}\operatorname{Ln} Y_{7}=5.038+0.013 X \\
(63.61)^{* *}(2.34)^{*}\end{array}$ \\
\hline
\end{tabular}

$* *$ Significant at the $1 \%$ probability level, $*$ Significant at the $5 \%$ probability level

\subsection{The contribution of local production in achieving self-sufficiency and food security for poultry meat}

A study of the local production's relative importance in achieving self-sufficiency and food security for poultry meat during 1990-2018 showed that local production met the local consumer needs by a minimum of $35.3 \%$ and a maximum of $75.1 \%$ with a $95 \%$ confidence level (Table 6). The food security policy of poultry meat depended on both domestic production and imports during the study period. Domestic production's relative importance helps to achieve the current food security level (food security factor: 0.42 ) for poultry meat ranging between 13.5 and $30.3 \%$, at a $95 \%$ confidence level.

Examination of the relative importance of local production to achieve food security for poultry meat and with the assumption that the relative importance of the import contribution was 0.201 during 1995-2018, the study revealed that local production contributed to the relative food security of poultry meat between 20.1 and $39.7 \%$ with a confidence level of $95 \%$ when the food security factor was at 0.5 (Table 7). To achieve the full food security level for poultry meat (food security factor: 1), local production's relative importance to achieving food security for poultry meat ranged between 63.9 and $95.9 \%$ at a confidence level of $95 \%$. 


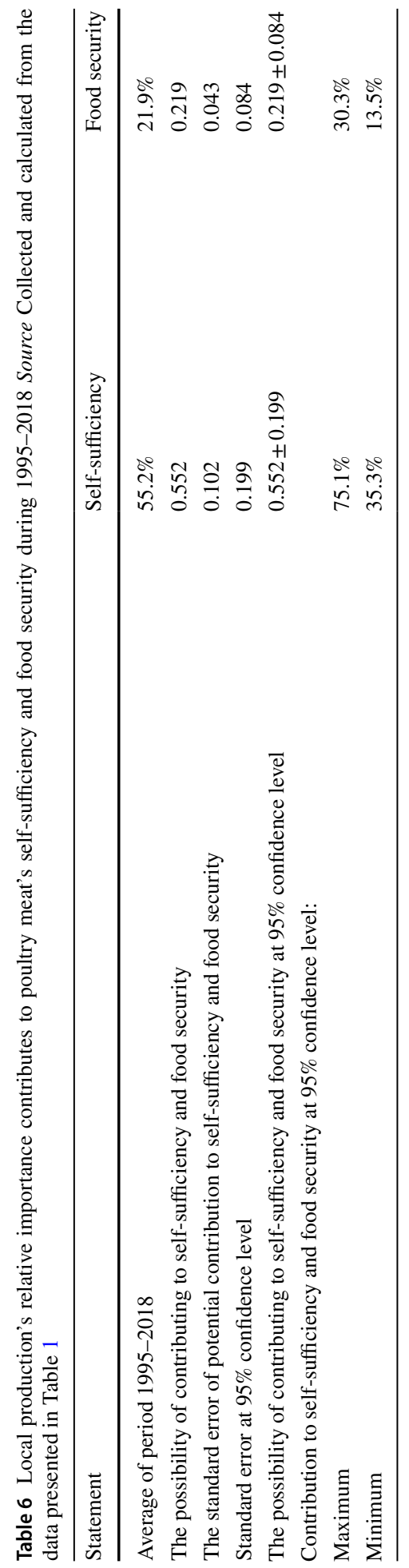




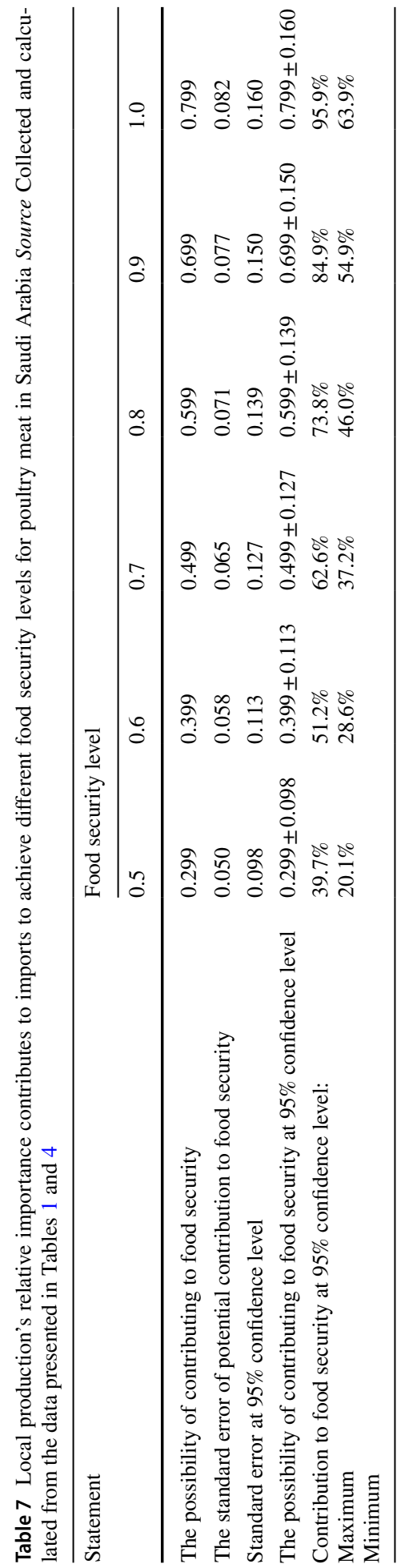




\subsection{Estimating the financing needs to achieve self-sufficiency and food security for poultry meat}

\subsubsection{Estimating the value of loans and investment needs to achieve self-sufficiency for poultry meat}

The past five years' data presented in Table (2) show that, given the local production and the value of loans granted by the Agricultural Development Fund for poultry projects, the average share of a ton of poultry meat in the loan values ranged between 311.3 Riyals/tons in 2014 and 514.5 Riyals/tons in 2015, with an annual average of 262.12 Riyals/tons during 2014-2018.

The loan and investment needed to achieve self-sufficiency are estimated based on the production required to satisfy local consumer needs (Table 8). The average share of poultry meat from loans granted to poultry projects amounted to 267 Riyals/tons during 2014-2018. The difference between the required production to achieve different levels of self-sufficiency and its equivalent in 2018 (1164.6 thousand tons) is expected to increase from 15.3 thousand tons (self-sufficiency rate $=75 \%$ ) to 408.6 thousand tons (self-sufficiency rate $=100 \%$ ). Additional loans are required for the poultry industry, obtained through new projects or the expansion of the existing projects' production capacity to increase self-sufficiency. The value of additional loans is expected to increase from 4.09 million Riyals, when the self-sufficiency rate reached $75 \%$, to 109.1 million Riyals, when the self-sufficiency rate reached $100 \%$. Considering the lending regulations of the Agricultural Development Fund, including the subsidized 50\% of the total investment costs of the projects to be established, the additional investment required to achieve self-sufficiency for poultry meat is twice the value of loans to be provided to meet the difference. The value of additional investments is expected to increase from 8.17 million Riyals, when the self-sufficiency rate reached $75 \%$, to 218.19 million Riyals, when the self-sufficiency rate reached $100 \%$.

\subsubsection{Estimating the amount of financing needed to achieve food security for poultry meat}

The financing needed to achieve food security included both loans and investment needed to expand domestic production and the value of imports. The loan and investment needed to achieve food security were estimated based on the required increase in domestic production to improve the strategic stock and the average share of a ton of poultry meat from the loans granted to poultry projects 267 Riyals/ton during 2014-2018. As shown in Table 9, domestic production should increase by 470.37 thousand tons to reach 0.5 of the food security coefficient. In contrast, domestic production will increase by 1256.95 thousand tons when the food security coefficient is equal to 1 , which requires additional loans for the poultry industry through the implementation of new projects or expansion of existing projects' production capacity. Additional loans are expected to increase from 125.59 million Riyals when the food security coefficient reached 0.5-335.6 million Riyals when the coefficient was 1. According to the Agricultural Development Fund's lending regulations, additional investment is expected to increase from 251.18 million Riyals when the food security coefficient is $0.5-671.21$ million Riyals when poultry's food security coefficient meat is equal to 1 . The overall financing needs to be increased from 1.89 billion Riyals to 


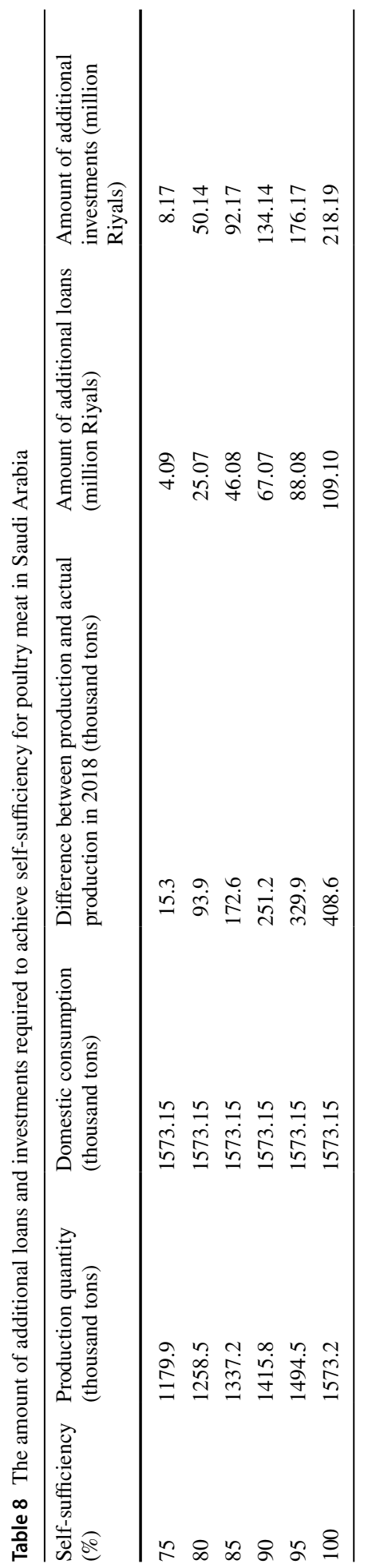




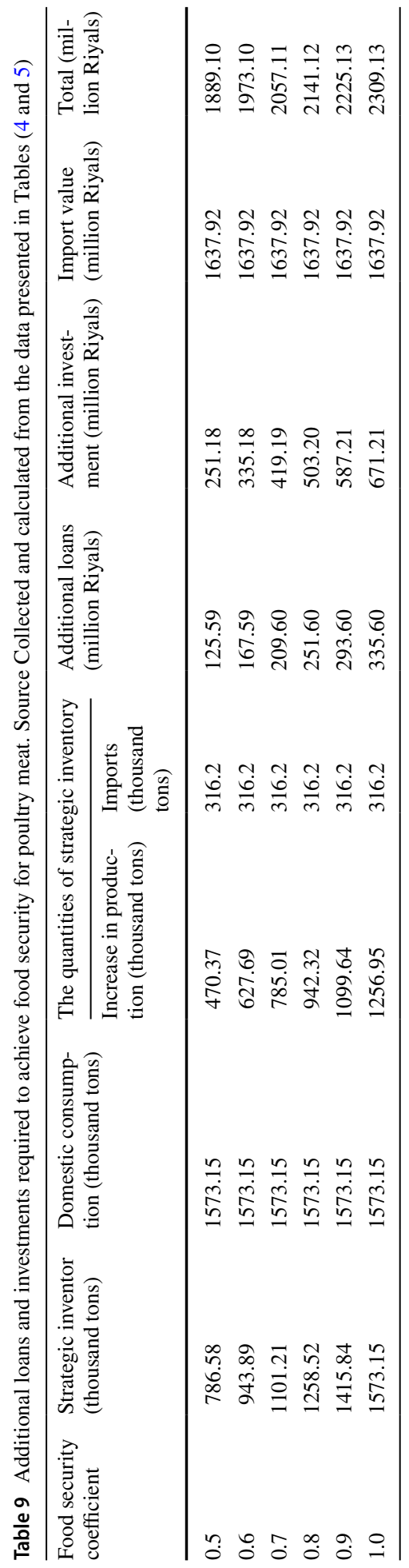


Table 10 Quantity and value of water used to achieve self-sufficiency and food security for poultry meat during 1995-2018 Source Collected and calculated from the data presented in Tables (1, 2, and 3)

\begin{tabular}{|c|c|c|c|c|c|c|}
\hline \multirow[t]{3}{*}{ Year } & \multirow{2}{*}{\multicolumn{2}{|c|}{ Self-sufficiency }} & \multicolumn{4}{|l|}{ Food security } \\
\hline & & & \multicolumn{2}{|l|}{ Surplus } & \multicolumn{2}{|l|}{ Deficit } \\
\hline & $\begin{array}{l}\text { Quantity } \\
\text { (Million m3) }\end{array}$ & Value (Million Riyals) & $\begin{array}{l}\text { Quantity } \\
\text { (Million m3) }\end{array}$ & $\begin{array}{l}\text { Value (Mil- } \\
\text { lion Riyals) }\end{array}$ & $\begin{array}{l}\text { Quantity } \\
\text { (Million m3) }\end{array}$ & $\begin{array}{l}\begin{array}{l}\text { Value } \\
\text { (Million } \\
\text { Riyals) }\end{array}\end{array}$ \\
\hline 1995 & 1558.2 & 751.06 & 320.6 & 154.54 & - & - \\
\hline 1996 & 1586.2 & 764.54 & 277.7 & 133.84 & - & - \\
\hline 1997 & 1801.9 & 868.53 & 10.0 & 4.81 & - & - \\
\hline 1998 & 1578.2 & 760.68 & 22.8 & 10.98 & - & - \\
\hline 1999 & 1670.1 & 804.98 & 5.8 & 2.79 & - & - \\
\hline 2000 & 1929.8 & 930.15 & - & - & 4.60 & 2.21 \\
\hline 2001 & 1897.8 & 914.75 & 348.0 & 167.74 & - & - \\
\hline 2002 & 1865.9 & 899.34 & 191.4 & 92.24 & - & - \\
\hline 2003 & 1869.8 & 901.27 & 264.5 & 127.49 & - & - \\
\hline 2004 & 2085.6 & 1005.26 & 15.0 & 7.22 & - & - \\
\hline 2005 & 2145.5 & 1034.15 & 19.2 & 9.24 & - & - \\
\hline 2006 & 2137.5 & 1030.29 & 39.4 & 18.97 & - & - \\
\hline 2007 & 2029.7 & 978.30 & 96.7 & 46.60 & - & - \\
\hline 2008 & 1835.9 & 884.90 & 124.3 & 59.89 & - & - \\
\hline 2009 & 1973.7 & 951.34 & 44.1 & 21.28 & - & - \\
\hline 2010 & 1785.9 & 860.82 & 105.3 & 50.74 & - & - \\
\hline 2011 & 2113.6 & 1018.74 & 138.6 & 66.82 & - & - \\
\hline 2012 & 2349.3 & 1132.36 & 210.4 & 101.39 & - & - \\
\hline 2013 & 2273.4 & 1095.77 & 313.2 & 150.98 & - & - \\
\hline 2014 & 2553.9 & 1230.96 & 5.8 & 2.79 & - & - \\
\hline 2015 & 2446.4 & 1179.16 & - & - & 56.5 & 27.25 \\
\hline 2016 & 2499.9 & 1204.96 & - & - & 20.8 & 10.01 \\
\hline 2017 & 2460.8 & 1186.09 & 145.6 & 70.19 & - & - \\
\hline 2018 & 4653.0 & 2242.77 & 13.0 & 6.26 & - & - \\
\hline Total & $51,102.0$ & $24,631.17$ & 2711.4 & 1306.8 & 81.9 & 39.47 \\
\hline
\end{tabular}

achieve a level of 0.5 for food security laboratories to 2.31 billion Riyals to achieve a full food security level (Table 9), because the relative importance of imports in achieving food security for poultry meat is stable.

\subsection{Estimating the quantity and value of the water used for achieving self-sufficiency and food security for poultry meat}

The amount of water used to achieve self-sufficiency for poultry meat is estimated using the product of the domestic production of poultry meat and the average water requirement or water footprint per ton of poultry meat of $3995.4 \mathrm{~m}^{3} /$ ton (Table 3 ).

Table 10 shows the amount of water used to achieve poultry meat's current self-sufficiency in 1995-2018. Water consumption increased from 1.56 billion $\mathrm{m}^{3}$ in 1995 to 4.65 
billion $\mathrm{m}^{3}$ in 2018. Assuming that the average cost of extracting groundwater is 0.482 Riyals $/ \mathrm{m}^{3}$ at a discount of $10 \%$ (Nashwan et al., 2016), the value of water used to achieve self-sufficiency increased from 751.06 million Riyals in 1995 to 2242.77 million Riyals in 2018.

The amount of water consumed to achieve poultry meat's current food security is measured by multiplying the amount of surplus and deficit in the average water requirements or the water footprint per ton of poultry meat. The total amount of water used to achieve the surplus for developing the strategic stock of poultry meat is 2.71 billion $\mathrm{m}^{3}$, with an estimated cost of 1,306.8 million Riyals. Meanwhile, the total amount of water used in the amount of deficit or withdrawal from the strategic stock is 81.9 million $\mathrm{m}^{3}$, with an estimated cost of 39.47 million Riyals during 1995-2018. The strategic stock is the outcome of both surplus and deficit; therefore, the amount of water used to achieve the strategic stock or the current food security of poultry meat is 2.63 billion $\mathrm{m}^{3}$, with an estimated value of 1,267.33 million Riyals. The amount of water used to achieve food security for poultry meat represents $5.15 \%$ of the total used in domestic production of poultry meat of 51.10 billion $\mathrm{m}^{3}$ during 1995-2018.

To increase self-sufficiency for poultry meat from 75 to $100 \%$, the amount of water needed should increase from 4.71 billion $\mathrm{m}^{3}$ at 2,272.2 million Riyals to 6.29 billion $\mathrm{m}^{3}$ at 3029.6 million Riyals (Table 11). To increase poultry meat's food security coefficient from 0.5 to 1 , the amount of water needed for production increases from 3.14 billion $\mathrm{m}^{3}$ at 1514.8 million Riyals to 6.29 billion $\mathrm{m}^{3}$ at 3029.5 million Riyals (Table 11).

Table 10. Quantity and value of water used to achieve self-sufficiency and food security for poultry meat during 1995-2018.

\section{Discussion and conclusion}

Achieving food scarcity is very challenging in Saudi Arabia due to the water scarcity and weather inclemency. The government has established increasing poultry production as one of its strategic efforts to provide food with the better and more efficient allocation of scarce water resources. This paper investigates trends for self-sufficiency and food security on poultry production and estimates the water and financial requirements to reach self-sufficiency and ensure food security in poultry.

During 1995-2018, the results showed that domestic poultry production increased by an average annual rate of $2.5 \%$, whereas daily local consumption increased at an annual rate of $4.4 \%$. Because consumption increased at a higher rate than domestic production, the proportion of self-sufficiency decreased from $68.9 \%$ in 1995 to $48.7 \%$ in 2017 . Nonetheless, with government facilitation providing financial loans to poultry producers, the rate of selfsufficiency then increased to $73.8 \%$ in 2018 . We also calculated the food safety coefficient during 1995-2018 that was equal to $42 \%$, meaning that the accumulated strategic poultry stock during our investigation will cover $42 \%$ of total consumption in 2018 , equivalent to the average daily consumption for only 152.7 days. Previous results have also arrived at the same conclusion regarding the existing gap between consumption and production and food insecurity. For instance, a study by the Riyadh Economic Forum (2012) indicated a gap between poultry consumption and production and estimated the expected coefficient for food security during 2011-2020 to be 52\%.

Since additional production requires additional investment, Alqunibet and Ghanem (2013) estimated the additional production cost required for food security from poultry 


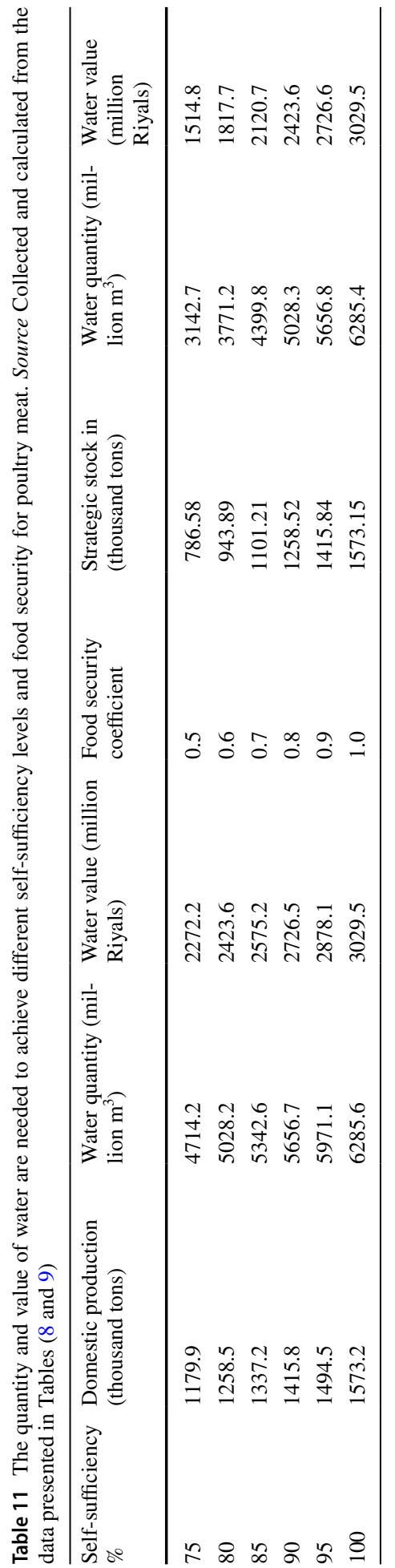


during 2012-2020 to be equivalent to 1752.32 million Riyals. Our analysis estimated both the financial and water needs to reach self-sufficiency and food security. The results suggest that Saudi Arabia should increase domestic production by 408.6 thousand tons to achieve self-sufficiency for poultry meat. This production level requires adding more investments up to 218.19 million Riyals and requires 1.58 billion $\mathrm{m}^{3}$ of water worth 757.7 million Riyals. To ensure food security from poultry meat, domestic production should be increased by 1256.95 thousand tons, which requires adding more investments worth 671.21 million Riyals and calls for an additional 3.15 billion $\mathrm{m}^{3}$ of water worth 1515 million Riyals.

The Saudi Government established the Agricultural Development Fund (Previously known as "The Saudi Agricultural Bank") to provide agricultural loans. The current regulations obliged the fund only to cover $50 \%$ of the total value of agricultural projects. Therefore, the fund will give loans up to 109.1 million Riyals and up to 335.6 million Riyals to reach self-sufficiency food security for poultry, respectively. Our results provide essential insights for policymakers to either amend the fund's current regulations or establish other means for poultry production to access greater financing. Also, any access to finance must be linked or contingent on water efficiency aligned with the government objective to provide food and an efficient allocation of scarce water resources.

Finally, this paper's major limitation is the use of aggregated data, ignoring the variations between projects regarding three aspects: economy of scale, geographical location, and the technology adopted. This warrants future studies to consider using more detailed data to consider these aspects when estimating financial and water requirements regarding self-sufficiency and food security for poultry meat.

Acknowledgement The authors would like to extend their gratitude to the Deanship of Scientific Research at King Saud University for funding this work through research group no. RG-1441-388.

\section{References}

Agricultural Development Fund (2019). Agricultural development fund strategy and transformation program 2016-2020.

Alamri, Y., \& Al-Duwais, A. (2019). Food security in Saudi Arabia (case study: Wheat, barley, and poultry). Journal of Food Security, 7(2), 36-39.

Alderiny, M. M., Alrwis, K. N., Ahmed, S. B., \& Aldawdahi, N. M. (2020). Forecasting Saudi Arabia's production and imports of broiler meat chickens and its effect on expected self-sufficiency ratio. Journal of the Saudi Society of Agricultural Sciences, 19(4), 306-312.

Alqahtani, S., Elhendy, A., Ismaiel, S., \& Sofian, B. (2017). Water resources management through the concept of virtual water trade at Kingdom of Saudi Arabia. King Abdulaziz City for Science and Technology. General Directorate of Research Grants Programs. Project \# AT-35-116.

Alqunibet, M., \& Ghanem, A. (2013). Forecasting the necessary loans and investments for poultry projects and distributing them to the productive areas in the kingdom of Saudi Arabia. Journal of Agricultural and Veterinary Sciences, Al-Qassim University, 2(1), 56-71.

Antamoshkina, E., \& Rogachev, A. (2019). Methodical approach to food security assessment and forecasting. In Volgograd State University International Scientific Conference" Competitive, Sustainable and Safe Development of the Regional Economy"(CSSDRE 2019) (pp. 184-187). Atlantis Press.

Cecilia, A., Lucian, L., Ionel, I., \& Grodea, M. (2017, June). The possibility to reach meat self-sufficiency in Romania in the long term. In Proceeding of the International Scientific Conference" Strategies For The Agri-Food Sector And Rural Areas-Dilemmas Of Development, 19-21.

Chapagain, A. K., \& Hoekstra, A. Y. (2003). Virtual water flows between nations in relation to trade in livestock and livestock products (No. 13). Delft: UNESCO-IHE.

Chen, Y., \& Nie, F. (2016). Analysis of china's food supply and demand balance and food security. In food security and industrial clustering in Northeast Asia. (pp. 47-59). Springer. 
Daghir N., Mourad R., \& Jaafar H. (2018). Animal and poultry production water footprint in the MENA region, VI Mediterranean poultry summit 18-20 June, Book of Abstracts-Plenary sessions, 6th MPSTorino-Italy-World's Poultry Science Journal, 74, 3.

Food and Agriculture Organization (2018). FAOSTAT database Website: http://www.fao.org/faostat/, period 1990-2018.

General Authority for Statistics (2019). Export and import statistics. www.stats.gov.sa/en. Riyadh, Saudi Arabia.

General Organization for Grains (2019). Baseline: Index of food loss and waste in Saudi Arabia, First Edition, pp. 41-63.

General Authority for Statistics (2019). Survey of specialized agricultural projects (broiler, ostrich, rabbit, quail, and pigeon farms). www.stats.gov.sa/en. Riyadh, Saudi Arabia.

Ghanem, A. (1997). The issue of food security in Egypt (An analytical study). . Al-Maaref Establishment.

Ghanem, A. K., Kamara, S. A., Alaagib, S. E. B., \& Aldawdahi, N. M. (2019). Estimating the value of investments and imports for achieving food security for fish. (pp. 1-15). Environment.

Ghanem, A., \& Kamara, S. (2010). A study of the specific economic factors for sugar food security laboratories in Egypt. The Third Conference of the department of agricultural economics and business administration (agricultural development strategy and Egyptian food security challenges), faculty of agriculture, Alexandria University, (28-29) July, Alexandria Journal of Agricultural Research, 56(2): $1-10$.

Greene, W. H. (2003). Econometric analysis. . New York University.

Ministry of Environment, Water, and Agriculture (2019). Statistical yearbook for 2018. www.mewa.gov.sa. Riyadh, Saudi Arabia.

Nashwan, O. S., Al-Qunaibet, M. H., \& Ghanem, A. M. (2016). Estimating groundwater extraction cost and its efficiency use in dates production in Riyadh region, Saudi Arabia. Custos E Agronegocio ON Line, 12(1), 282-289.

Oki, T., Sato, M., Kawamura, A., Miyake, M., Kanae, S., \& Musiake, K. (2003). Virtual water trade to Japan and in the world. In Hoekstra, AY 'Virtual water trade: Proceedings of the International Expert Meeting on Virtual Water Trade', Value of Water Research Report Series (Vol. 12).

Riyadh Economic Forum (2012). Food security study between domestic agriculture, Import and Foreign Agricultural Investment, Fifth Session, (17-19) December.

Saudi Arabia's 2030 Vision (2030). Kingdom of Saudi Arabia. https://www.vision2030.gov.sa/en.

USDA, Foreign Agricultural Service, (2020). Saudi Arabia poultry and products annual. https://www.fas. usda.gov/data/saudi-arabia-poultry-and-products-annual-6

Water Footprint Network Website. (2020). https://waterfootprint.org. Accessed 19 January 2020.

Zimmer, D., \& Renault, D. (2003). Virtual water in food production and global trade: review of methodological issues and preliminary results. In Virtual water trade: Proceedings of the International Expert Meeting on Virtual Water Trade. Value of Water Research Report Series (No. 12).

Publisher's Note Springer Nature remains neutral with regard to jurisdictional claims in published maps and institutional affiliations. 